\title{
STRATEGI PENYELEMATAN RIMBA YANG TERSISA DARI ILLEGAL LOGGING
}

\author{
Yuniarti Dwi Pratiwi ${ }^{1}$
}

\begin{abstract}
Abstrak: Pada dasarnya permasalahan yang paling krusial Negara Indonesia, di bidang lingkungan hidup, khususnya kehutanan adalah illegal logging (pembalakan liar). Bahkan kejahatan di bidang kehutanan ini, telah berkembang menjadi kejahatan terorganisir lintas batas negara, yang tentunya akan berdampak pada bangsa ini, yakni kerugian kekayaan dan menjadi ancaman baru bagi kedaulatan bangsa ini. Mengingat pentingnya penaganan illegal logging yang lebih terpadu, maka Pemerintah mengeluarkan Undang-Undang Nomor 18 Tahun 2013 tentang Pemberantasan Perusakan Hutan. Namun, cukup disayangkan diterbitkannya Undang-Undang ini, menuai pro dan kontra, karena masih terdapat beberapa kelemahan.
\end{abstract}

Kata Kunci: Illegal Logging, Kejahatan Teroganisir Lintas Batas Negara, Peraturan.

\section{PENDAHULUAN}

Pembangunan selalu membawa dampak terhadap perubahan lingkungan. Segala variasi ditempuh dalam wujud apa pun dalam pembangunan, berarti pula menuntut perubahan lingkungan. Semakin meningkatnya upaya pembangunan maka akan makin meningkat pula dampaknya terhadap lingkungan hidup. Pembangunan ini kemudian ditunjang dengan bergulirnya Otonomi Daerah yakni UndangUndang Nomor 22 Tahun 1999 tentang Pemerintahan Daerah (yang telah dicabut oleh Undang-Undang Nomor 34 Tahun 2004 tentang Pemerintahan Daerah).

Sejalan dengan Otonomi Daerah, Pemerintah Daerah mempunyai kewenangan untuk mengelola sumberdaya hutan, yakni berupa pemanfaatan hutan. Akan tetapi pemanfaatan hutan pada era otonomi daerah sering kali menimbulkan kerusakan. Banyak kalangan menilai bahwa kebijakan otonomi daerah tersebut akan semakin meningkatkan volume kerusakan hutan, yang diakibatkan pembalakan liar atau illegal logging. Alasan mendasar dari pernyataan tersebut adalah bahwa kondisi faktual dalam implementasi otonomi daerah mencerminkan adanya kecenderungan daerah dalam kebijakan pengelolaan hutan di daerahnya berorientasi pada Pendapatan Asli Daerah (PAD).

Pembalakan liar merupakan kejahatan multidimensional. Stephen Deveinish, ketua Misi Forest Law Enforcement Governance and Trade (FLEGT) dari Uni Eropa, mengatakan bahwa penebangan liar (illegal logging) adalah penyebab utama kerusakan hutan di Indonesia dan menjadi masalah serius di dunia.
Penebangan liar (illegal logging) ini telah menimbulkan masalah multidimensi yang berhubungan dengan aspek ekonomi, sosial, budaya, dan lingkungan. Hal ini merupakan konsekuensi logis dari fungsi hutan yang pada hakekatnya adalah sebuah ekosistem yang didalamnya mengandung tiga fungsi dasar, yaitu produksi (ekonomi), fungsi lingkungan (ekologi), dan fungsi sosial.

Praktek penebangan liar (illegal logging) saat ini terjadi hampir di seluruh pelosok Indonesia. Laporan World Bank menyebutkan bahwa sejak otonomi daerah, angka deforestasi hutan meningkat tiap tahunnya, yaitu mencapai lebih dari 3,0 (tiga koma nol) juta hektar per tahun (1998-2001), dari sebelumnya 1,6 (satu koma enam) juta hektar - 2,0 (dua koma nol) juta hektar per tahun. Berdasarkan data dari Departemen Kehutanan tahun 2003 menyebutkan bahwa luas hutan Indonesia yang rusak mencapai 43 juta hektar dari total 120,35 hektar dengan laju degradasi dalam tiga tahun terakhir mencapai 2,1 juta hektar pertahun. Data terbaru dari Departemen Kehutanan menyebutkan bahwa laju kerusakan hutan di Indonesia telah mencapai 3,8 juta hektar per tahun dan negara telah kehilangan Rp. 83 Milyar per hari akibat illegal logging. ${ }^{3}$

Maraknya pembalakan liar atau illegal logging ini, sudah seharusnya menjadi perhatian serius bagi pemerintah dan seluruh elemen masyarakat. Ini tidak lain, dikarenakan sumber daya kehutanan, merupakan sumber daya alam yang memiliki peran ganda. Hutan berperan sebagai modal pertumbuhan ekonomi (resource based economy), disisi lain berperan sebagai penyangga sistem kehidupan (life support

\footnotetext{
${ }^{1}$ Yuniarti Dwi Pratiwi, SH adalah alumnus Fakultas Hukum UGM, anggota Divisi Kajian Lembaga Kajian Pertahanan untuk kedaulatan NKRI "KERIS". Penulis dapat dihubungi melalui email dialamat: ciko_cute63@yahoo.co.id

${ }^{2}$ Sukardi. 2005. Illegal Logging Dalam Perspektif Politik Hukum Pidana (Kasus Papua). Yogyakarta: Universitas Atma Jaya Yogyakarta, hlm. 3

${ }^{3}$ Khakim, Abdul. 2005. Pengantar Hukum Kehutanan Indonesia Dalam Era Otonomi Daerah. Bandung: P.T. Citra Aditya Bakti, hlm. 1
} 
system) dan sumber kemakmuran rakyat, sebagaimana yang ditegaskan di dalam Pasal 33 Undang-Undang Dasar 1945 yang sebagai landasan konstitusional hukum kehutanan, menegaskan "Bumi, air, dan kekayaan alam yang terkandung di dalamnya dikuasai oleh Negara, dan dipergunakan untuk sebesar-besarnya kemakmuran rakyat." Oleh karena itu, dengan adanya pembalakan liar atau illegal logging ini, akan mempengaruhi perekonomian dan tingkat kemakmuran rakyat Indonesia, yang secara tidak langsung maupun langsung akan mempengaruhi tingkat ketahanan nasional.

Lebih lanjut, lemahnya perlindungan dan penegakan hukum atas kejahatan kehutanan yakni illegal logging disebabkan oleh praktek yang hanya menggunakan salah satu undangundang misalnya Undang-Undang Nomor 41 Tahun 1999 tentang Kehutanan. Disebut lemah karena salah satu sebabnya adalah argumen bahwa sudah memiliki ijin manjadi alasan kuat untuk lolos dari jeratan Undang-Undang Nomor 41 Tahun 1999. Dengan kata lain aspek administratif menjadi peluang untuk menutupi penyimpangan yang ada. Padahal dalam perkara pidana yang diutamakan adalah kebenaran materiil, apalagi potensi penyimpangan dalam hal keluarnya ijin itu sendiri cukup besar. Sedangkan dalam proses beracara kejahatan pembalakan liar, dakwaan yang dikenakan kepada para terdakwa adalah menggunakan delict pencurian atau ketentuan pidana yang diatur di dalam Pasal 78 Undang-Undang Nomor 41 Tahun 1999. Ancaman pidana UndangUndang yang disangkutkan oleh penyidik tersebut berkisar 5-10 tahun meskipun dikumulatifkan dengan dendan, belum memberikan efek jera kepada pelaku kejahatan kehutanan.

Ironisnya, kejahatan illegal logging (pembalakan liar) sekarang disinyalir merupakan kejahatan yang melintasi batas yurisdiksi suatu negara, dan dalam perkembangan kekinian illegal logging (pembalakan liar), secara langsung atau tidak langsung dapat mempengaruhi dan mengancam keamanan nasional. Hal ini dapat dipahami karena watak dan wajah ancaman keamanan nasional telah berubah menjadi multi dimensional. Ancaman keamanan nasional, tidak hanya berupa ancaman militer, tetapi juga termasuk ancaman politik, ekonomi, sosial budaya maupun lingkungan (ekologis).
Berangkat dari kondisi ini, maka diperlukan suatu pendekatan penegakan hukum yang lebih terpadu, terintegrasi, dan komprehensif, seperti penggunaan perangkat anti korupsi dan anti pencucian uang. Hal ini dimaksudkan untuk bisa memberikan efek jera terhadap pelaku tindak pidana kehutanan, dan mendapatkan hasil yang lebih baik untuk melindungi sektor kehutanan kita. Oleh karena itu, pemerintah mengelurkan Undang-Undang Nomor 18 Tahun 2013 tentang Pemberantasan Perusakan Hutan. Akan tetapi, hadirnya Undang-Undang ini menambah benang kusut dalam penegakan tindak pidana illegal logging, karena mempunyai banyak kelemahan salah satunya tumpang tindih antara beberapa sektor. Seperti yang pernah disinggung oleh Prof Maria S Sumardjono menyebutkan, betapa regulasi sumber daya alam Indonesia saling bertabrakan (conflicting). ${ }^{4}$ Kenyataan inilah yang menimbulkan sebuah keharusan untuk harmonisasi regulasi kehutanan, guna mendorong percepatan perlindungan kawasan hutan Indonesia.

\section{METODE PENELITIAN}

Peneliti berusaha untuk meneliti strategi penanggulangan pembalakan liar dengan menggunakan penelitian deskriptif kualitatif. Penelitian ini terbatas pada usaha mengungkapkan suatu masalah atau keadaan atau peristiwa sebagaimana adanya sehingga bersifat sekedar untuk mengungkapkan fakta (fact finding). ${ }^{5}$ Dengan penelitian deskriptif tersebut, maka peneliti menggunakan data yang bersumber dari dokumen, buku, penelitian lain, media massa. Guna melakukan analisis mendalam tentang pola strategi penanggulangan pembalakan liar, maka digunakalah tipe penelitian berupa analisis dokumen (analysis of documents atau documentary analysis). Penelitian ini menggunakan teknik pengumpulan data analisis dokumen dengan melakukan pengumpulan dokumen dari lembaga resmi (CIFOR dan KEMENTERIAN KEHUTANAN), buku, undang-undang dan peraturan lainnya, jurnal dan berbagai artikel media massa. Teknik ini disebut juga sebagai teknik dokumenter atau studi pustaka. Teknik studi pustaka adalah cara mengumpulkan data yang dilakukan dengan kategorisasi dan klasifikasi bahan-bahan tertulis yang berhubungan dengan masalah penelitian, baik dari sumber dokumen maupun buku-buku, koran, majalah, dan lain-lain. ${ }^{6}$

\footnotetext{
${ }^{4}$ Kompasiana.Pro dan Kontra UU Pemberantasan Perusakan Hutan. http://green.kompasiana.com/penghijauan/2013/08/13/pro dan-kontra-uupemberantasan-perusakan-hutan-580773.html, diakses pada 18 Agustus 2013

${ }^{5}$ Nawawi, Hadari.1990. Metode Penelitian Bidang Sosial, Yogyakarta: Gadjah Mada University Press. hlm. 31

${ }^{6}$ Arikunto, Suharimi.2006. Prosedur Penelitian Suatu Pendekatan Praktik, Jakarta: Rineka Cipta. hlm. 231
} 


\section{PERSOALAN KEHUTANAN INDONESIA}

Secara umum deforestasi di Indonesia terjadi akibat konversi hutan untuk berbagai peruntukan, baik yang sudah direncakan maupun yang tidak direncanakan. Deforestasi yang direncanakan adalah konversi ${ }^{7}$ yang terjadi di kawasan hutan produksi yang dapat dikonversi (HPK) yang dilepaskan untuk menjadi kawasan budidaya non kehutanan. Konversi ${ }^{8}$ yang direncanakan dapat juga terjadi di kawasan hutan produksi untuk pertambangan terbuka. Sedangkan deforestasi yang tidak direncakanan terjadi akibat konversi hutan yang terjadi di semua kawasan hutan akibat berbagai kegiatan yang tidak terencana, terutama kegiatan illegal logging atau pembalakan liar.

Sementara itu degradasi hutan terjadi sebagai akibat dari pengelolaan hutan yang dilaksanakan secara tidak lestari oleh para pemegang izin (IUPHHK) Hutan Alam ${ }^{9}$ atau karena penebangan yang dilakukan oleh para pihak yang tidak memiliki Izin Usaha Pemanfaatan Hasil Hutan Kayu (IUPHHK) ${ }^{10}$ Hutan Alam. Kegiatan ini menyebabkan kondisi tegakan hutan mengalami penurunan karena laju pemanenan kayu lebih besar dari pertumbuhan (tiap) pohon. Persoalannya, kerusakan hutan dan pembangunan diatasnya dilaksanakan belum berdasarkan prinsip keadilan. ${ }^{11}$

\section{KEJAHATAN LINTAS BATAS NEGARA}

Berbagai kejahatan terorganisir, baik yang dilakukan perseorangan maupun oleh sekumpulan orang dalam ruang lingkup batas suatu negara kini semakin meningkat. Kejahatan tersebut dilakukan secara terorganisir dengan keterkaitan berbagai pihak. Bahkan, keberadaan batas teritorial kini bukan lagi halangan bagi perkembangan kejahatan tersebut. Keadaan ini melahirkan bentuk kejahatan terorganisir berskala internasional tanpa terikat pada batas kewilayahan. Bentuk kejahatan ini dikenal dengan kejahatan terorganisir lintas batas negara (transnational organized crime).

Menurut Michael Woodiwiss, yang dimaksud sebagai kejahatan terorganisir lintas batas negara adalah kejahatan yang dilakukan secara terorganisir dan telah berkembang meliputi beberapa bagian dunia, tanpa terikat pada batasbatas kewilayahan suatu negara atau kolektifitas masyarakat internasional. ${ }^{12}$ Kejahatan terorganisir lintas batas negara ini tak mudah untuk dideteksi karena memiliki sistem organisasi yang rapi, melibatkan banyak pihak dengan sokongan modal yang besar dan tidak mengenal batasan kewilayahan. ${ }^{13}$

Kejahatan yang dimaksud meliputi perdagangan narkoba, perdagangan manusia, penyuapan, perjudian, perdagangan gelap senjata, kegiatan terorisme, korupsi, kejahatan di bidang perbankan, kejahatan di bidang lingkungan, dan berbagai kejahatan lainnya yang terorganisir, diselundupkan dan diperdagangkan secara rapi, melibatkan modal besar, serta mengindikasikan adanya penyalahgunaan kekuasaan dari berbagai pihak. ${ }^{14}$

Keberlangsungan kejahatan lintas batas negara ini bertumpu pada keberadaan modal besar yang berperan sebagai penyokong sistem finansial kejahatan tersebut. Salah satu kejahatan yang telah menyita perhatian dunia adalah kejahatan di bidang kehutanan.

\section{FAKTOR PENDORONG KESUSAKAN HUTAN}

Beberapa faktor pendorong kerusakan hutan di antaranya adalah: 1) Krisis ekonomi; 2) Perubahan tatanan politik; 3) Lemahnya koordinasi antaraparat penegak hukum; 4) Adanya kolusi, korupsi dan nepotisme; 5) Lemahnya sistem pengamanan hutan dan pengamanan hasil hutan, dan 6) Harga kayu hasil

\footnotetext{
Hutan produksi adalah kawasan hutan yang mempunyai fungsi pokok memproduksi hasil hutan

Konversi merupakan perubahan pemilikan atas suatu tanah, hutan atau sebagainya ke dalam bentuk lainnya

9 Hutan Alam merupakan yaitu suatu lapangan yang bertumbuhan pohon-pohon alami yang secara keseluruhan merupakan persekutuan hidup alam hayati beserta alam lingkungannya. Hutan alam juga disebut hutan primer, yaitu hutan yang terbentuk tanpa campur tangan manusia ${ }^{10}$ Izin usaha pemanfaatan hasil hutan kayu yang selanjutnya disingkat IUPHHK adalah izin usaha yang diberikan untuk memanfaatkan hasil hutan berupa kayu dalam hutan alam pada hutan produksi melalui kegiatan pemanenan atau penebangan, pengayaan, pemeliharaan dan pemasaran. Dalam Pasal 31-59 Peraturan Pemerintah Nomor 6 Tahun 2007 tentang Tata Hutan dan Penyusunan Rencana Pengelolaan Hutan, Serta Pemanfaatan Hutan, Izin Usaha pemanfaatan Hutan Produksi terdiri dari a) Izin Usaha Pemanfaatan Kawasan; b) Izin Usaha Pemanfaatan Jasa Lingkungan; c) Izin Usaha Pemanfaatan Hasil Hutan Kayu dalam hutan alam; d) Izin Usaha Pemanfaatan Hasil Hutan Kayu dalam hutan tanaman; e) Izin Usaha Pemanfaatan Hasil Hutan Bukan Kayu dalam hutan alam; f) Izin Usaha Pemanfaatan Hasil Hutan

Bukan Kayu dalam hutan tanaman; g) Izin Pemungutan Hasil Hutan Kayu dalam hutan alam; h) Izin Pemungutan Hasil Hutan Bukan Kayu dalam hutan alam; i) Izin Pemungutan Hasil Hutan Bukan Kayu dalam hutan tanaman.

${ }^{11}$ Kementrian Kehutanan Direktorat Jenderal Direktorat Jenderal Wilyah Pengelolaan dan Penyiapan Areal Pemanfaatan

Kawasan Hutan. 2011. Pembangunan Kesatuan Pengelolaan Hutan (KPH), Konsep, Peraturan, dan Implementasi. Jakarta. hlm 14

${ }^{12}$ Edwards, Adam \& Gill, Peter. 2004. Transnational Organised Crime: Perspectives on Global Activity. New York: Routledge, hlm. 14

${ }^{13}$ Nurhadiyanto, Lucky. 2010. Pola Pencucian Uang Hasil Perdagangan Narkoba dan Pembalakan Liar. Jurnal Kriminologi Indonesia 6(2). Agustus 2010.hlm. 159

${ }^{14}$ Ibid, hlm. 160

${ }^{15}$ Santoso, Topo. 2011. Panduan Investigasi dan Penuntutan dengan Pendekatan Hukum Terpadu. Bogor: Center

For International Forestry Research. hlm. 5
} 
tebangan liar yang lebih murah. ${ }^{15}$

Berdasarkan kelompok pengusaha, para pelaku perusakan hutan dapat diklasifikasikan dalam Tabel 1 sebagai berikut: ${ }^{16}$

\begin{tabular}{|c|c|}
\hline Pelaku & Peranan \\
\hline $\begin{array}{l}\text { Pengusaha } \\
\text { Puth }\end{array}$ & $\begin{array}{l}\text { Memiliki izin resmi, baik untuk } \\
\text { kelompok HPH/HPHTI maupun } \\
\text { kelompok industri. Dengan } \\
\text { mengacu pada izin pemerintah, } \\
\text { areal kerja resmi berdasarkan peta } \\
\text { kerja Rencana Umum Tata Ruang, } \\
\text { Rencana Tata Ruang Wilayah } \\
\text { Propinsi dan Rencana Tata Ruang } \\
\text { Wilayah Kabupaten, maka } \\
\text { keberadaan usaha sektor } \\
\text { kehutanan selama belum direvisi } \\
\text { masih sah menurut hukum }\end{array}$ \\
\hline $\begin{array}{l}\text { Pengusaha } \\
\text { Abu-Abu }\end{array}$ & $\begin{array}{l}\text { Memiliki izin usaha yang didapat } \\
\text { setelah Orde Baru dan setelah } \\
\text { pelaksanaan otonomi daerah, yang } \\
\text { secara yuridis berlaku apabila } \\
\text { bebas dari pertikaian atau tumpang } \\
\text { tindih kewenangan. Namun } \\
\text { kenyataannya, peraturan lahir } \\
\text { selama masa reformasi banyak } \\
\text { yang memiliki tumpang tindih } \\
\text { kewenangan sehingga dipandang } \\
\text { lemah. }\end{array}$ \\
\hline $\begin{array}{l}\text { Pengusaha } \\
\text { Hitam }\end{array}$ & $\begin{array}{l}\text { Mumi melakukan kegiatan } \\
\text { melawan hukum atau tindak } \\
\text { pidana seperti penebangan di } \\
\text { hutan lindung, penyerobotan } \\
\text { kawasan, pencurian kayu dan } \\
\text { pemalsuan dokumen }\end{array}$ \\
\hline
\end{tabular}

Tabel 1. Klasifikasi Kelompok Pengusaha Sektor Kehutanan Berdasarkan Perizinan

\section{DEFINISI ILLEGAL LOGGING}

Pengertian "illegal logging" dalam peraturan perundang-undangan yang ada tidak secara eksplisit didefinisikan dengan tegas. Namun, terminologi illegal logging dapat dilihat dari pengertian secara harfiah yaitu dari bahasa inggris. Dalam The Contemporary English Indonesian Dictionary artinya tidak sah, dilarang atau bertentangan dengan hukum. ${ }^{17}$ Sedangkan karena melihat luasnya jaringan kejahatan penebangan liar (illegal logging) yang mencerminkan luasnya pengertian dari penebangan liar (illegal logging) itu sendiri, bahwa penebangan liar (illegal logging) :
"Penebangan liar"...occur right through the chain from source to costumer, from illegal extraction, illegal transport and processing trought to illegal export and sale, where timber is often laundered before entering the legal market."

Gambaran tentang penebangan liar (illegal logging) menurut pendapat ini menunjukkan adanya suatu rangkaian kegiatan yang merupakan suatu rantai yang saling terkait, mulai dari sumber atau produser kayu illegal atau yang melakukan penebangan kayu secara ilegal hingga ke konsumen atau pengguna bahan baku kayu. kayu tersebut melalui proses penyaringan yang illegal, pengangkutan illegal dan proses eksport atau penjualan illegal. Proses penebangan liar ini, dalam perkembangannya semakin nyata terjadi dan seringkali kayu-kayu illegal dari hasil penebangan liar itu dicuci (dilegalkan) terlebih dahulu sebelum memasuki pasar yang legal, artinya bahwa kayu-kayu yang pada hakekatnya adalah illegal, dilegalkan oleh pihak-pihak tertentu yang bekerja sama dengan oknum aparat, sehingga kayu tersebut memasuki pasar, maka akan sulit lagi diidentifikasi mana yang merupakan kayu illegal dan mana yang merupakan kayu legal. ${ }^{18}$

\section{FAKTOR-FAKTOR MEMPENGARUHI ILLEGAL LOGGING}

Menurut Dudley bahwa ada tiga faktor yang menyebabkan suburnya illegal pada tingkat lokal dan yang memungkinkan illegal meluas dengan cepat, yaitu:

A. Faktor-faktor yang berkaitan dengan nilainilai masyarakat dan situasi penduduk di desa-desa dekat hutan yang dipengaruhi oleh unsur-unsur: a) Kebutuhan lapangan kerja dan pendapatan; b) Pengaruh tenaga kerja lain yang sudah bekerja secara illegal; c) Ketidakpuasan lokal atas kebijakan kehutanan pusat; d) Dukungan terhadap pengelolaan hutan lestari.

B. Faktor-faktor ekonomi suplai dan perminataan normal berkaitan dengan industri penebangan kayu dipengaruhi oleh unsur-unsur seperti :a) Kebutuhan kapasitas terpasang industri kayu dalam negeri dan permintaan kayu dari luar negeri; b) Kemampuan pasokan kayu dan kebijakan jatah kayu tebangan; c) Tinggi rendahnya laba dari perusahaan industri kayu.

C. Faktor-faktor yang berkaitan dengan pengusaha dan pengaruhnya pada, serta

\footnotetext{
${ }^{16}$ Ibid. hlm. 7

${ }^{17}$ Nurdjana, IGM. 2008. Korupsi dan Illegal Logging Dalam Sistem Desentralisasi. Yogyakarta: Pustaka Pelajar. hlm. 13

${ }^{18}$ Ibid. hlm. 14
} 
kolusi dengan, para politisi dan pemimpin setempat dipengaruhi oleh unsur-unsur seperti : a) Keuntungan yang diperoleh oleh pengusaha kayu; b) Besarnya pengaruh pengusaha kayu dan bos-bos penebangan terhadap pejabat lokal; c) Besarnya partisipasi pejabat lokal dalam kegiatan illegal logging; dan d) Banyaknya kerjasama illegal yang dilakukan oleh pengusaha dengan penguasa atau pejabat lokal. ${ }^{19}$

\section{PELAKU DALAM KEJAHATAN ILLEGAL LOGGING}

A. Masyarakat setempat dan masyarakat pendatang. Pelaku ini melakukan kegiatan penebangan secara langsung baik untuk kepentingan sendiri maupun untuk dijual kepada pengusaha kayu atau pemilik modal. Laju perusakan hutan akibat kegiatan yang dilakukan oleh pelaku ini relatif kecil oleh karena modal dan peralatan yang dimiliki masih terbatas;

B. Pemilik modal (cukong), pengusaha. Pelaku ini berperan sebagai fasilitator atau penadah hasil kayu curian, bahkan menjadi otak dari pencurian kayu;

C. Pemilik industri kayu. pelaku ini masih berperan sebagai turut serta melakukan, atau membantu melakukan penyelundupan kayu atau illegal logging;

D. Oknum pejabat pemerintah atau oknum aparat pemerintah. Pelaku ini bisa berasal dari oknum TNI, oknum Polri, PNS Kehutanan, PNS Beacukai, oknum pemerintah daerah, oknum anggota DPRD, dan oknum politisi. Pelaku ini bisa terlibat KKN dengan pengusaha dan atau melakukan manipulasi kebijakan dalam pengelolaan hutan atau pemberian konsesi penebangan yang dapat menimbulkan kerusakan hutan;

E. Pengusaha asing. Pelaku ini kebanyakan berperan sebagai pembeli atau penadah hasil kayu curian. ${ }^{20}$

\section{PENANGANAN ILLEGAL LOGgING BERDASARKAN UU NO. 41 TAHUN 1999}

Umumnya penanganan tindak pidana di bidang kehutanan seperti illegal logging hanya diproses berdasarkan ketentuan dalam UU Kehutanan. karena itu subyek kejahatan di bidang kehutanan, hanyalah perorangan sebagai pelaku perbuatan dan/atau pengurus suatu badan hukum atau badan usaha yang terkait dengan kejahatan di bidang kehutanan. Berikut Alur Penanganan Kejahatan di Bidang Kehutanan Berdasarkan UU No. 41 Tahum 1999.

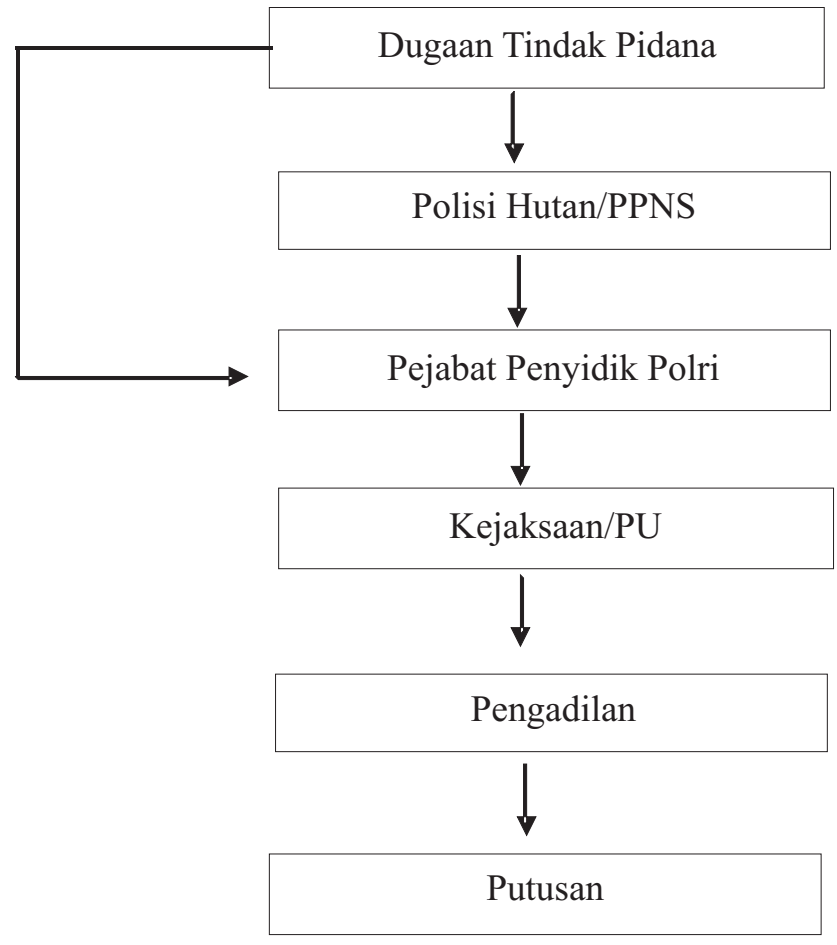

Sementara itu, ada pihak-pihak lain dalam mata rantai kejahatan ini yang tidak dapat dipidana apabila penegak hukum hanya mendasarkan pada UU Kehutanan. Pihak-pihak lain yang dimaksud antara lain adalah (1) pejabat pemerintah yang berwenang untuk mengeluarkan perizinan dan (2) pengusaha/pemilik modal yang secara tidak langsung terkait dengan badan usaha/badan hukum yang melanggar ketentuan bidang kehutanan. ${ }^{21}$

\section{PERANGKAT HUKUM DALAM PENANGGULANGAN ILLEGAL LOGGING}

Selain Undang-Undang Kehutanan, seharusnya undang-undang lain dapat juga digunakan untuk menjerat berbagai pihak yang terlibat melakukan tindak pidana di sektor kehutanan. misalnya, UU Pemberantasan Tindak Pidana Korupsi dapat digunakan untuk menangani pejabat yang terlibat dalam mengeluarkan surat/ijin/dokumen tertentu untuk membantu pihak lainnya melakukan pembalakan liar. Demikian juga UU Pencegahan dan Pemberantasan Tindak Pidana Pencucian Uang

\footnotetext{
${ }^{19} \mathrm{lbid}, \mathrm{hlm} .94$

${ }^{20} \mathrm{Ibid}, \mathrm{hlm} .102$

${ }^{21}$ Santoso, Topo, OpCit, hlm. 12
} 
(TPPU) dapat digunakan untuk menjerat para pelaku kejahatan kehutanan yang mengaburkan asal-usul hasil kejahatan tersebut agar mereka bisa menikmatinya.

Selanjutnya, barang bukti dalam kejahatan di bidang kehutanan yang didapat oleh penyidik lapangan, seperti semua hasil hutan dari hasil kejahatan dan alat-alat (termasuk alat angkutnya) yang digunakan untuk melakukan kejahatan, akan dirampas untuk negara. Apabila dilihat sebagai unsur mata rantai, maka harta pelaku kejahatan yang patut diduga didapatkan dari hasil kejahatannya di bidang kehutanan juga perlu dipertanyakan. Hal ini dilakukan mengingat kerugian yang timbul akibat perbuatannya tersebut tidak hanya ditanggung oleh publik, namun juga merusak keseimbangan lingkungan hidup.

Dalam hal sanksi yang diberikan kepada pelaku kejahatan di bidang kehutanan terdapat sanksi pidana dan administratif, serta keharusan untuk membayar ganti rugi sesuai dengan tingkat kerusakan atau akibat yang ditimbulkan kepada negara, seperti biaya rehabilitasi, pemulihan kondisi hutan, atau tindakan lain yang diperlukan. Oleh karena itu, untuk memberi efek jera kepada pelaku dalam mata rantai kejahatan di bidang kehutanan, dan melihat luasnya dampak kejahatan lingkungan yang harus ditanggung oleh publik, maka penegak hukum juga perlu mendasarkan penanganan suatu perbuatan kejahatan di bidang kehutanan pada ketentuan peraturan perundang-undangan selain UU Kehutanan. $^{22}$

Sementara itu, terkait dengan pengenaan Undang-Undang Tindak Pidana Korupsi terhadap kasus tindak pidana illegal logging, KPK (Komisi Pemberantasan Korupsi) menjadi lembaga yang utama dalam penanganan kasus korupsi kehutanan, akan tetapi tidak semua kejahatan kehutanan ada unsur korupsi karena bukan domain KPK. Inilah yang tampaknya Pemerintah ingin menjawab dengan dikeluarkannya UU Nomor 18 Tahun 2013 dengan salah satu pasalnya yaitu mendirikan Lembaga Pemberantasan Perusakan Hutan $(\mathrm{LP} 2 \mathrm{H}){ }^{23}$

\section{KELEBIHAN DAN KEKURANGAN UNDANG-UNDANG NOMOR 18 TAHUN 2013}

UU Nomor 18 Tahun 2013 tentang Pemberantasan Perusakan Hutan (P2H) merupakan metamorfosis RUU Pemberantasan Illegal Logging yang diusulkan pertengahan dekade 2000-an. Frase illegal logging diperkenalkan karena ketiadaan terminologi yang tepat saat itu. Di Indonesia, frase illegal logging kerap dipakai EIA/Telapak melalui serangkaian publikasi tentang penebangan hutan Indonesia secara ilegal. Undang-Undang in dibentuk, karena UU nomor 41 tahun 1999 tentang Kehutanan belum mampu menjerat para pelaku perusak hutan. Alhasil, mafia perusak hutan tidak tersentuh oleh hukum. UU Nomor 18 Tahun 2013 memang dirancang untuk menjerat korporasi pelaku perusakan, bukan menjerat per orang. Karenanya, keberadaan masyarakat adat di hutan juga tak akan disingkirkan dan tidak pula mereka disebut merusak hutan. Disamping itu, dalam salah satu pasal pada Undang-Undang mengamanahkan untuk segera membentuk lembaga pengawas, yang merupakan gabungan gabungan dari kejaksaan, kepolisian, pemerintah, dan masyaraka sipil.

Namun, Undang-Undang ini menuai cukup banyak kelemahan. Salah satu frasa dalam UU Nomor 18 Tahun 2013, yakni Pasal 84 menyebutkan bahwa, "barangsiapa membawa alat-alat yang lazim dipakai untuk menebang, memotong, atau membelah pohon dalam kawasan hutan akan dipidana 2-15 tahun penjara dan denda Rp 1 miliar hingga Rp 7,5 miliar". Jika yang membawa penduduk sekitar hutan dipidana 3 bulan-10 tahun penjara dan denda Rp 0,5 miliar-Rp 5 miliar. Bagaimana dengan anggota pencinta alam yang menjelajah hutan membawa golok atau penduduk yang biasa memegang parang untuk mencari pakan ternak atau penduduk yang membawa golok saat mencari madu hutan. Selain itu, dalam UU Nomor 18 Tahun 2013, dari total 12 pasal yang mengatur ketentuan pidana, 2 pasal hanya menambahkan mekanisme pemidanaan, 2 pasal mengatur pidana yang dilakukan pejabat negara, 1 pasal mengenai kejahatan korporasi, dan 7 pasal mengatur pidana-pidana perbuatan langsung. Terlihat bahwa UU Nomor 18 Tahun 2013 tentang P2H tidak diperuntukkan bagi otak kejahatan (master mind), tetapi hanya para pelaku langsung yang umumnya adalah rantai terendah dalam kejahatan terorganisasi atau pelaku tunggal yang biasanya adalah masyarakat lokal yang miskin. Adanya 1 pasal mengenai kejahatan korporasi di dalam UU Nomor 18 Tahun 2013 pun tak sesuai harapan karena sanksinya diwakilkan ke pengurus serta tiadanya sanksi kompensasi

\footnotetext{
${ }^{22}$ Ibid. hlm. 14

${ }^{23}$ Kompasiana.Pro dan Kontra UU Pemberantasan Perusakan Hutan.http://green.kompasiana.com/penghijauan/2013/08/13/pro dan-kontra-uupemberantasan-perusakan-hutan-580773.html, diakses pada tanggal 18 Agustus 2013

${ }^{24}$ Ibid
} 


\section{LANGKAH PENANGGULANAN KEJAHATAN ILLEGAL LOGGING}

Terjadinya illegal logging, pada dasarnya menunjukkan tidak adanya sense of belonging dari masyarakat dan terdapat manipulasi oleh pemilik modal untuk kepentingan usaha mereka, smentara rakyat hanya menanggung beban kerusakan sumber daya hutan. Oleh karena itu, pengendalian illegal logging perlu dlakukan dengan melibatkn masyarakat secara langsung dalam pengelolaan hutan, bukan sebagai buruh tetapi sebagai bagian penting (subyek) dan hendaknya mengacu pada prinsip-prinsip dan prespektif pengelolaan ekosistem dan membangun kesejahteraan masyarakat di lingkungan hidup. Tujuan ini tidak lain guna masyarakat merasa ikut memiliki dan ikut bertanggung jawab terhadap perlindungan hutan, serta ikut mengawasi para pelaku bisnis illegal logging.

Pemberdayaan integritas moral penegak hukum, visi dan misi pemberatasan illegal logging, dengan menyatukan cara pandang yang sama yaitu menempatkan korupsi dalam praktik illegal logging yang merugikan keuangan dan ekonomi negara milyaran atau triliyunan rupiah, juga merupakan hal yang terpenting. Sebagai implementasi integritas moral penegakan hukum dapat berupa konsistensi pelaksanaan berbagai kesepakatan bersama antarinstansi penegak hukum dan instansi terkait dalam upaya penanggulangan dan pemberantasan illegal logging termasuk korupsi diperlukan lembaga kontrol yang ketat internal maupun eksternanl

Perihal telah dikeluarkannya UndangUndang Nomor 18 Tahun 2013 tentang Pemberantasan Perusakan Hutan yang cukup tumpang tindih, hemat penulis pemerintah harus mengevaluasi kebijakan standar ganda tentang pengelolaan hutan dan kebijakan perkebunan maupun pertanian. Harmonisasi hukum ini, antara UU dengan peraturan Kehutanan lain sangat diperlukan. Tujuan ini tidak lain, agar tidak menciptakan peluang deforestasi dan degradasi hutan secara besar-besar dalam bentuk skala besar.

\section{KESIMPULAN}

A. Bahwa tindak pidana illegal logging yang terjadi di Indonesia telah merusak hutan yang ada dan tidak hanya merugikan negara tetapi juga telah menjadi tranasional crime, karena melewati lintas batas Negara, sedangkan penegakan hukum terhadap tindak pidana illegal logging dirasakan belum optimal dan belum sampai menyentuh otak pelaku / pemilik modal (cukong) nya.

B. Kurang optimalnya penegakan hukum terhadap illegal logging ini disebabkan banyak faktor diantaranya adalah lemahnya koordinasi antar aparat penegak hukum dan instansi terkait, adanya oknum-oknum aparat yang terlibat illegal logging. Serta regulasi tindak pidana Illegal logging sebagaimana yang diatur di dalam Undang-Undang Nomor 41 Tahun 1999 masih mempunyai kekurangan dan celah dalam menjerat mafia kehutanan.

C. Untuk mencegah semakin merajalelanya tingkat kerusakan hutan berpadu dengan lemahnya penegakan hukum, maka sangat diperlukan suatu regulasi-regulasi lain seperti Undang-Undang Tindak PIdana Korupsi, dan Undang-Undang Tindak Pidana Pencucian Uang, guna memberangus mafiamafia kehutanan terutama white collar crime. Oleh karena itu Pemerintah mengeluarkan Undang-Undang Nomor 18 Tahun 2013 tentang Pemberantasan Perusakan Hutan;

4. Disahkan Undang-Undang Nomor 18 Tahun 2013 ini, disinyalir tetap memliki banyak kelemahan. Kelemahan-kelemahan itu dapat terlihat dari subtansial isi Pasal-Pasal yang terdapat di dalam UU ini, sehingga menimbulkan multiinterpretasi dari beberapa kalangan dalam penindakan tindak pindak Illegal logging 
Khakim,Abdul.2005.Pengantar Hukum Kehutanan Indonesia Dalam Era Otonomi Daerah. P.T. Citra Aditya Bakti.Bandung.

Edwards, Adam \& Gill, Peter. 2004. Transnational Organised Crime: Perspectives on Global Activity. Routledge.New York.

Nawawi, Hadari. 1990. Metode Penelitian Bidang Sosial.Gadjah Mada University Press.Yogyakarta.

Nurhadiyanto, Lucky. 2010. Pola Pencucian Uang Hasil Perdagangan Narkoba dan Pembalakan Liar.Jurnal Kriminologi Indonesia .6(2). Agustus 2010176.

Nugraha, Satriya. Kompasiana.Pro dan Kontra UU Pemberantasan Perusakan Hutan. http://green.kompasiana.com/penghijauan/2 $013 / 08 / 13 / p r o-d a n-k o n t r a-u u-$ pemberantasan-perusakan-hutan580773. html, diakses pada 18 Agustus 2013.

Nurdjana, IGM. 2008. Korupsi dan Illegal Logging Dalam Sistem Desentralisasi.Pustaka Pelajar.Yogyakarta.

Santoso, Topo. 2011. Panduan Investigasi dan Penuntutan dengan Pendekatan Hukum Terpadu. Center For International Forestry Research.Bogor

Suharimi, Arikunto. 2006. Prosedur Penelitian Suatu Pendekatan Praktik. Rineka Cipta. Jakarta,

Sukardi. 2005. Illegal Logging Dalam Perspektif Politik Hukum Pidana (Kasus Papua). Universitas Atma Jaya Yogyakarta. Yogyakarta.

Undang-Undang Nomor 18 Tahun 2013 Pemberantasan Perusakan Hutan.6 Agustus 2013. Lembaran Negara Republik Indonesia Tahun 2013 Nomor 130. Jakarta

Nomor 41 Tahun 1999

Kehutanan.30 September 1999. Lembaran Negara Republik Indonesia Tahun 1999 Nomor 167. Jakarta

Peraturan Pemerintah Nomor 6 Tahun 2007 Tata Hutan dan Penyusunan Rencana Pengelolaan Hutan, Serta Pemanfaatan Hutan.8 Januari 2007. Lembaran Negara Republik Indonesia Tahun 2007 Nomor 22. Jakarta
Kementrian Kehutanan. Direktorat Jenderal Direktorat Jenderal Wilyah Pengelolaan dan Penyiapan Areal Pemanfaatan Kawasan Hutan.2011.Pembangunan Kesatuan Pengelolaan Hutan (KPH), Konsep, Peraturan, dan Implementasi. Jakarta 